\title{
GOVERNANCE AS A TOOL FOR BUSINESS DEVELOPMENT IN NIGERIA
}

\author{
Blessing Prince Nwanganga \\ Abia State Polytechnic, Aba
}

\section{$\boldsymbol{\&}$}

Success Anaba

Abia State Polytechnic, Aba

\begin{abstract}
Governance matters are arguably at the core of international development. This paper addresses the role theory, policy and practice play in shaping matters of governance as it concerns business development in Nigeria. The paper is organised in three parts, In the first part, the theories on the governance and development nexus are outlined. In the second, the role of governance and its relevance to business development is discussed; here, the concepts, principles and framework for enhanced governance in business are brought to the fore, selected reviews by scholars and practitioners and numerous current key issues are highlighted. In the third part, the impact of governance in business practice is examined. Reviews and current issue related to the impact of governance in business development are also discussed. Besides, lessons are drawn from the review of contributions from selected scholars. The conclusion of this paper is threefold: first, it is a fallacy that there is a preeminent system of governance that is universally applicable for business development; second, the relevant theories on the subject have a remarkably limited role to play in sculpting policy and practice; and, third, perhaps the single most important problem in policies and practices on governance for development is the failure to temper interventions to the contextual dynamics found in each developing country setting.
\end{abstract}

\section{Introduction}

The origin of multinational enterprises dates back to the early fifteenth and sixteenth centuries when European business companies started moving to various parts of the globe (Akanegbu, 2014; Awolusi, 2012; Awolusi, 2012b), since the mid-1970s, multinational corporations have rapidly expanded business activities on a worldwide basis through foreign direct investment (Otokiti, 2012). For example, the British East India Company (1599-1858) and the Hudson's Bay Co. and the Royal African Co. were also created in the same way by British merchants with the objective of trading with America and Africa respectively (Akanegbu, 2014). These were the predecessors of the modern multinational corporations. Since World War II, the dimensions of multinational corporations have grown and spread with phenomenal speed. The international petroleum industry, however, predates this more recent development (Akanegbu, 2014).

A typical multinational corporation normally functions with the headquarters based in one country, while other facilities are based in locations in other countries. In some circles, a multinational corporation is referred to as a multinational enterprise or a transnational corporation (Tatum, 2010). They enter host countries in different ways and with different strategies.

Some enter by exporting their products to test the market and to find whether their existing products can gain a sizeable market share. For such firms, they rely on export agents. These 
foreign sales branches or assembly operations are established to save transport costs because there is a limit to what foreign exports can achieve for a firm owing mainly to tariff barriers and quotas and also owing to logistics or cost of transportation. To meet the growing demands in foreign countries, the firm considers other options such as licensing or foreign direct investment which are critical steps. Some continue with export even when they have settled for the foreign direct investment option. Every step takes strategic planning and is motivated by profit through sales growth (Osuagwu and Ezie, 2013).

It is interesting to know that, many African (Nigeria inclusive) countries still do not allow free entry of multinational firms and often express preferences about the type of FDI; unfortunately, there is little in the literature that helps to understand such policies, other than the standard argument that certain industries can secure greater protection for themselves than others, perhaps it may also be the case that positive spillovers to the local economy are perceived to be higher under certain types of FDI than others (Saggi, 2002). However, despite the subtle policy interventions outlined above, Saggi maintained that, when measured by a broad yardstick, overall government policy has become more liberal across the world, with intense competition for strategic trade and FDI from developed and 'emerging nations' by most developing countries.

Due to the perceived benefits associated with them, political and economic decisions by elected governments are increasingly made to provide favourable environments for the investment and marketing needs of multinational corporations. Consequently, multinational firms are sometimes able to influence the domestic policy outcomes of host developing countries by threatening to move jobs overseas (Abdul-Gafaru,2006). Nigeria has played host to multinational corporations long before independence till date. The number and activities of these multinational corporations have grown over time as Nigeria struggles to develop socioeconomically as a nation.

After over fifty years of nationhood, the economic growth trajectory of Nigeria is at best cheered despite the growing presence of these multinational corporations in its core sectors of oil, banking and manufacturing sectors (Awolusi, 2012; Onudogo, 2012). The study of Otokiti (2012) revealed that challenges faced by multinational firms during entry into the Nigerian market include government regulations and policies, geographical location, language barrier, shortage of skilled labour, and low level of technological development. From a technology transfer perspective, weak levels of intellectual property protection in developing countries prevent both down-stream and up-stream technology transfer activities; the fear of the unauthorized use of proprietary knowledge prevents foreign companies from entering into technology transfer activities with local entities(down-stream technology transfer); on the other hand, it also deprives local innovators of the opportunity to license their inventions to foreign entities (up-stream technology transfer)(Awolusi, 2012; Awolusi, 2012b; Diamant, Davison andPugatch, 2007). According to Iyela (2009), corruption increases the cost of doing business and as such foreign investors would prefer to invest in countries with lower rates of corruption which is believed to derive maximum profits from their investments. He added that the insecurity which manifests in kidnappings, hostage-taking and deaths of innocent souls automatically discourage foreign investment. Instead, firms will prefer countries with peaceful investment environments (Oregwu and Onuoha, 2013). Besides, firms operating in Nigeria face an acute human capital deficit, particularly at the managerial levels (UNCTAD, 2009). It has been observed that because of poor governance and inept leadership, corruption has become pandemic in Nigeria. This, according to studies, has prevented the political leaders from giving 
special attention to investment in human capital development, which provides the knowledge and skills that workers acquire through education, training, and experience (Dike, 2012). Employers of labour have been complaining that most of the recent university graduates lack employability skills and problem-solving abilities and other competencies which are the main variables that determine an individual worker's productivity capabilities as well as the ability to contribute meaningfully to national development (Dike, 2012).

In its 2008 Review of World Development, the United Nations Development Programme (UNDP) ranked Nigeria157 out of 177 in Human Capital Development Index, Nigeria was also among the "Least Liveable" nations (Dike,2012). Consequently, this paper is intended to determine the extent to which multinational firms have spurred up economic development in Nigeria. For this purpose, this paper is structured into five sections: the first section focuses on the general introduction; the second section focuses on the review of literature; the third section focuses on the methodology; the fourth section discusses our findings and its implications on economic development in Nigeria; while the last section presents the conclusion.

\section{Literature review}

\section{Conceptual clarifications}

Hill (2005) defines a multinational corporation (MNCs) as any business that has productive activities in two or more countries. Certain characteristics of multinational corporations should be identified at the start since they serve, in part, as their defining features. Often referred to as "multinational enterprises," and in some early documents of the United Nations they are called "transnational organizations," multinational corporations are usually very large corporate entities that while having their base of operations in one nation - the "home nation"—carry out and conduct business in at least one other, but usually many nations, in what is called the "host nations." Multinational corporations are usually very large entities having a global presence and reach (Kim, 2000).

Multinational corporations(MNCs) can spur economic activities in developing countries and provide an opportunity to improve the qualities of life, economic growth, and regional and global commons (Litvin,2002). Tadaro (1999) cited in Ileoma (2010) see multinational corporations as enterprises that conduct and control productive activities in more than one country. UNCTAD (2000) maintains that foreign direct investment contributes to economic growth through technology transfer with the multinational firms transferring technology either directly to their foreign-owned enterprises or indirectly to domestically owned and controlled firms in the host country. Following Lucas (1988) argument, foreign direct investment spurs long-run growth through such variables as research and development (R\&D) and human capital. It is suggested that through technology transfer to their affiliates and technological spill-over to unaffiliated firms in the host economy, foreign companies can speed up the development of new intermediate product varieties, raise product quality, facilitate international collaboration on research and development (R\&D), and introduce new forms of human capital (Subair and Salihu, 2011).

Furthermore, most multinational corporations are set up to maximize profit at the lowest possible cost. So the idea of investing in a foreign land is not to better the lot of the host nation but to exploit as much as is possible to develop the home country (Ozoigbo and Chukuezi, 2011). Also, the perceived inadequacies in human capital will undoubtedly hinder and inhibit the investible interest of foreign investors. This may not be unconnected with the fact that 
multinational companies (MNCs) most times require the competence of highly skilled and specialized workers to start (Olise, Anigbogu, Okoli, and Anyanwu, 2013).

\section{Multinational corporations and economic development}

Multinational Corporations are those having operations in more than one country. They are subjects to changes in international exchange rates, tariffs, duties, and restrictions on trade. The most successful ones have established production points where labour is cheap and secures affordable transportation to deliver to their markets (Otokiti, 2012). Many multinationals use outsourcing and subcontracting to reduce their tax liabilities and avoid government regulations (Otokiti, 2012). Multinational corporations contribute to 65\% of the non-governmental employment opportunities available at any given country of the host (Reid, 2001cited in Tirimba and Macharia, 2014). In 1998, multinational corporations had 19million employees in developing countries and were also responsible for more than 100 million jobs created indirectly through multiplier effects (Quinlivan, 2005).

The economic role of multinational corporations is simply to channel physical and financial capital to countries with capital shortages. As a consequence, wealth is created, which yields new jobs directly and through "crowding-in" effects. Besides, new tax revenues arising from multinational corporations' generated income, allowing developing countries to improve their infrastructures and to strengthen their human capital. By improving the efficiency of capital flows, multinational corporations reduce world poverty levels and provide a positive externality that is consistent with theUnited Nations' (UN) mission - countries are encouraged to cooperate and to seek peaceful solutions to external and internal conflicts (Quinlivan, 2005). In all, Multinational corporations (MNCs) can spur economic activities in developing countries and provide an opportunity to improve the qualities of life, economic growth, and regional and global commons (Litvin, 2002).

\section{Multinational corporations and technology transfers}

Numerous channels exist through which InternationalTechnology Transfer (ITT) may occur; trade in goods and services is a good example since all imports and exports bear some potential for transmitting technological information; imported capital goods and technological inputs can directly improve productivity by being used in production processes (Hoekman et al., 2004). Another channel is FDI since multinational enterprises (MNEs) generally transfer technological information to their subsidiaries, some of which may 'leak' into the host economy (Aitken et al., 1997; Awolusi,2012.). Horizontal (or intra-industry) spillovers may also take place when "local firms learn about new technologies, marketing or management techniques by observing foreign affiliates operating in their industry or by hiring workers trained by foreign affiliates and in this way improve their performance" (Javorcik \& Spatareanu, 2008, p.197). Conversely, Vertical (forward and backwards) spillover is the transfer of knowledge to local firms in the upstream sectors, through the supply of factor inputs to the MNEs; usually, via deliberate contacts with local suppliers or by more stringent requirements for product quality (Thompson, 2002).

\section{Theoretical and empirical review}

Many theoretical and empirical studies have identified several channels through which FDI from MNCs may positively or negatively affect economic growth and development; theoretically, some identified channels include increased capital accumulation in the host country, improved the efficiency of indigenous firms, via contract and demonstration effects, and their exposure to fierce competition, technological change, and human capital 
augmentation and increased exports (Aitken et al., 1997; Awolusi, 2012; Buckley, Clegg, and Wang, 2002; Buckley, Clegg, Wang, and Cross, 2002; Buckley, Clegg, and Wang, 2006; Buckley, Wang, and Clegg,2007).

According to Buckley et al. (2002, 2006), the extent to which FDI contributes to growth depends on the economic and social condition of the host country; although host countries with high rate of savings, open trade regime and the high technological product would benefit from increased FDI to their economies, MNCs may hurt the growth prospect of the host economy if they give rise to a substantial reverse flows by the activities of the MNCs, in the form of remittances of profits, dividends and substantial concessions from the host country (Ikiara, 2003; Akinlo,2004). Through initial macroeconomic stimulus, FDI is thought to contribute to economic growth and development, by raising total factor productivity and efficiency of resource use in the host economy through transfer of more advanced technology and organizational forms directly to MNCsaffiliates in the host country; besides, FDI could also trigger technological and other spillovers to locally owned enterprises, assisting human capital formation, contributing to international trade integration, helping to create a more competitive business environment, enhancing enterprise development and general improvement in environmental and social conditions of the host country (Ikiara, 2003; Awolusi, 2012).

The Heckscher - Ohlin Theorem states that countries tend to export the goods whose production is intensive in factors with which they are abundantly endowed (Mahe, 2005); due to lack of capacity development, Nigeria relies on United States, UK and Western Europe for the importation of strategic capital goods like machinery and equipment, where it lacks comparative advantage, while the greater percentage of her exports, mostly primary products, is targeted toward U.S markets. According to neoclassical theory, FDI influences income growth by increasing the amount of capital per person, but does not influence long-run economic growth due to diminishing returns to capital; also, recent endogenous growth theorists (Romer, 1986 and Lucas, 1988), argue that FDI spurs long-run growth through such variables as research and development $(\mathrm{R} \& \mathrm{D})$ and human capital. They suggest that, through technology transfer to both affiliates and unaffiliated firms in the host economy, MNCs can speed up the development of new intermediate product varieties, raise product quality, facilitate international collaboration on $\mathrm{R} \& \mathrm{D}$, as well as, the introduction of new forms of human capital. (Romer, 1986 and Lucas, 1988; Awolusi, 2012b).

Many empirical works have also been provided on the causal relationship between FDI from MNCs and economic growth and development; at the firm level, several studies provided evidence of technological spillover and improved plant productivity, while, at the macro level, FDI inflows in developing countries tend to "crowd in" other investment; however, most studies found that FDI inflows led to higher per capita GDP, increase economic growth rate and higher productivity growth (Markusen \& Venables, 2005; Akinlo, 2004). Other important channels of significant FDI and growth and development relationships include higher exportin host country and increased backwards and forward linkages with affiliates to multinationals (Markusen \& Venables, 2005); however, the role of host country factors of production in determining the extent of foreign capital productivity must not be underestimated, these factors comprise among others, the introduction of advanced technology, absorptive capacity in the host country, level of human capital in a recipient economy and some degree of complementarity between domestic investment and FDI (Akinlo, 2004; Awolusi, 2012). 
However, in a deviation from many studies, few empirical studies, especially those using firmlevel data, observed the insignificant impact of FDI on economic growth and development and that FDI is no more productive than domestic investments (Kumar,1996). Nevertheless, by controlling for simultaneity bias, country-specific effects, and proper use of lagged dependent variables in growth regressions, Carkovic and Levine (2002) observed positive impacts. Some of the studies showed marginal macroeconomic impacts, with FDI actually crowding out local investments and other types of foreign flows in some countries, and adversely affecting their current accounts (Ikiara, 2003).

Besides, there are many pieces of literature on trade policy; for instance, by examining a domestic firm's incentives for technology adoption given the existence of a superior technology that has already been adopted by a foreign rival, Miyagiwa and Ohno (1995) assumed a declining cost of adoption over time, while the main interest of the study was to examine how nature (tariff versus quota) and the duration(temporary versus permanent) of trade protection influence the domestic firm's incentive for technology adoption. Grossman and Helpman (1995) also analysed the effects of tariff protection in a two-country quality ladders model; although, they only analyzed tariffs that are too small to allow domestic firms to capture the market, the model, however, assumed Bertrand competition on the product market so that a low quality firm can monopolize the market only if a tariff of sufficient magnitude is imposed on higher-quality imports (Saggi, 2002).

\section{Methodology}

The study used scholarly journals, articles, and textbooks to review the activities of multinational firms with Nigeria's economic development, in terms of economic growth and development, technology transfers and policy issues.

\section{Findings and discussions}

Multinational companies are seen by some as threats to national identities and wealth and are accused of riding roughshod over national laws and of exploiting cheap labour. The emergence of multinational companies as powerful actors of the international business environment inevitably means that an important part of 'going global' is to find ways to effectively manage and control business organizations in different host countries (Ibidunni, 2009). Those who view multinational firms as engines of economic development maintain that multinational firms contribute resources that are generally not available or insufficiently available, namely: capital, technology, managerial and marketing skills and create jobs and alleviate balance of payment deficits of their host states through import substitution industrialization (Chukwuemeka, Anazodo, and Nzewi, 2011). Multinational companies present specific regulatory problems to ensure socially responsible conduct, particularly when they operate in developing countries where the regulatory mechanisms are relatively weaker. In Nigeria, the activities of some multinational companies have been identified as questionable or even unethical because of the harms they perpetrate on the society (Trevino, 2000 cited in Hashimu and Ango, 2012).

Multinational firms have been indicted for offering bribes and alleged corrupt practices to secure competitive advantages. For example, Sagem SA of France is a French-based hightechnology company in the Safran Group. It is a world and European leader in solutions and services in optronics, avionics, electronics and critical software for the civilian and military market, and maintains a presence in more than 20 countries. The Group has 54,500 employees in over 30 countries. The Safran Group reported a€10.329 billion revenue and a net profit of $€ 256$ billion in 2008 (Otusanya, Lauwo, and Adeyeye, 2012). The company's code of ethics 
states that the group's goals are founded on values shared by all personnel. It is corporate policy to ensure that the conduct of business complies with high standards of honesty, integrity and professional excellence. By upholding these values, the group remains worthy of the trust placed in it by its customers, personnel, shareholders, suppliers and partners. The Nigerian Federal Government in 2001 awarded the contract for the National Identity Card (NIC) project to theFrench firm Sagem SA for the sum of \$214 million (N26.75billion). Despite its claim of ethical business conduct, high standard of honesty and integrity, it was alleged in 2003 that Sagem SA spent huge funds on supporting the ruling party (People's Democratic Party) in the form of campaign donations and special Obasanjo/Atiku campaign billboards (ThisDay,14th December 2003 cited in Otusanya, et al, 2012). Upon further investigation by the Independent Corrupt Practice and other Related Offences Commission (ICPC), it was discovered that some government officials were actually bribed through the company's business partner in Nigeria (Otusanya, et al, 2012).

\section{MNCs and economic growth and development in Nigeria}

Over the years, the Nigerian economy has experienced a series of reforms and restructuring of its various key sectors. Such reforms include the financial, petroleum, power sector, among others. The financial sector has been the most noticeable beneficiary of the reforms as the banks and insurance companies were asked to recapitalize/consolidate in line with government regulatory requirements. The telecommunications industry also experienced a major transformation when the general system for mobile telecommunications (GSM) was introduced in 2001. The deregulation of the downstream petroleum sector and privatization of many previously government-owned parastatals also represent some of the many structural changes that have been made in recent years. In nominal terms, the size of the economy as measured by the country's gross domestic product (GDP) has increased by a compound annual growth rate of $20.68 \%$ between 2001 and 2007. An important trend in the economy's growth is the increasing contribution of the non-oil sector, particularly the agricultural and telecommunication sectors to the nation's gross domestic product (GDP) (Equity Research Report, 2009).

In Nigeria, corruption has become the order of the day happening among the young and the old, the politician and the non-politician as well as military and the non-military. Corruption gives room for diversion of the limited public funds, undermines economic progress and impedes policy changes required for development. On the whole, corruption impedes growth and also erodes the already established economic value systems in Nigeria. Nigeria is ranked among the most corrupt countries of the World (Transparency International, 2005 cited in Rotimi, Obasaju, Lawal, and Ise Olorunkanmi, 2013). Corruption wastes the limited resources of an economy, increases the costs of doing business thus signalling inflation, hence radically reduce revenues accrued to the state (Rotimi, Obasaju, Lawal, and Ise Olorunkanmi, 2013).

Nigeria is generously endowed with abundant natural resources including biological and nonbiological resources. The significance of agriculture resources in bringing about economic growth and sustainable development of a nation cannot be underestimated. Agriculture contributes to the growth of the economy, provides employment opportunities for the teeming population, export revenue earnings and eradicates poverty in the economy (Olajide, Akinlabi, and Tijani, 2012). The authors found that the agricultural sector contributes significantly to Nigeria's gross domestic product(GDP). The employment base of the Nigerian economy is largely dependent on this sector. Their findings showed that the agricultural sector contributes more than 30 per cent of the economy. 
The activities of multinational corporations are supportive of the growth and development of many countries including Nigeria. Multinational corporations are capable of contributing to the growth of real output direct investment in the production of tangible goods in the economy. The presence of multinational firms in host countries reduces the host countries' propensity to import and leads to increased competition in the host countries which promote efficient allocation of production resources (Bakare, 2010).

Nigeria has witnessed a high inflow of foreign direct investment as a result of investment in the Global System of Mobile (GSM) telecommunication. The oil sector of the economy has also witnessed an increased level of foreign direct investment as evidenced by the increasing numbers and operations of oil multinational corporations in the country (Ilemona, 2010). Multinational enterprises transfer technology directly to their foreign-owned enterprises and indirectly to domestic owned firms in host countries. Spill overs of advanced technology from foreign-owned enterprises can take any of these four ways: vertical linkages between affiliates and domestic suppliers and consumers, horizontal linkages between the affiliates and firms in the same industry in the host country, labour turnover from affiliates to domestic firms and internationalization of research and development. The pace of technological change in organizations as a whole will depend on the innovative and social capabilities of host countries together with the absorptive capacity of other enterprises in the country (Ayanwale, 2007).

Successful worldwide distribution of goods and services, expansion of employment opportunities especially for the world's poorest people, pronounced economic growth through foreign direct investment; and the creation of pure and practical knowledge through research and development and the global implementation of technological breakthroughs are some of the benefits of multinational corporations in the host countries' economy (Cundiff, 2000).

Multinational firms increase investment levels and income in the host countries, promote improvement in their immediate environment, create access to high-quality managerial skills, improve the balance of payment of the host countries by increasing exports and decreasing imports; help to equalize the costs of factors of production. They stimulate domestic production and enhance efficiency and effectiveness in the production process; they stimulate positive responses from local operators. Most well-known Nigerian entrepreneurs started by working for the multinational corporations, where they acquired relevant skills and knowledge that gave them the impetus to launch out (Osuagwu and Ezie, 2013).

\section{MNCs and technology transfer in Nigeria}

Given the importance of trade, many scholars opined that international trade can make a decisive contribution to sustainable development by promoting the equitable integration of Nigeria into the global economy, which can significantly boost economic growth; however, trade and investment liberalization will provide maximum benefit to Nigeria when it is operating within a sound supporting domestic policy framework and pursued in tandem with political will" (Mahe, 2005). Although tariffs provide the Nigerian government with its secondlargest source of revenue after oil exports, to increase the country's technology capabilities, imports policies revision in march 2003, led to the reduction of tariff on strategic imports, mostly raw materials, base metals, and capital equipment, to as low as 2.5percent; notwithstanding these efforts by Government, the poor level of Intellectual Property Rights (IPR) protection due to poor enforcement of intellectual property laws, has been described as one of the barriers to innovation and technology acquisition in the country (Akinlo, 2004). 
Given the pattern of FDI flows to Nigeria (mostly in the oil sector) and the apprehensions as regards the benefits from extractive FDI, several factors suggest that the indirect benefits of FDI may be less in the extractive (especially oil) industries; this is because the extractive sector (such as the oil subsector) is often an enclave sector with little linkages with the other sectors. Moreover, the transfer of technology between foreign firms and domestic ones may be less in extractive industries where the technology often embodied is extremely capital intensive, (Akinlo, 2004). Furthermore, Akinlo (2004) also posits that backward and forward linkages in technology transfer are less important in extractive FDI, as production in natural or primary resource sector requires fewer inputs of materials and intermediate goods from local suppliers due to its high capital intensive nature cum the fact that sales are foreign market-oriented.

Based on recent trends, there is high expectation that much of this investment would be supported by private international inflows, mainly from China, Russia and the Middle East; there is also an expectation of a continued influx of capital from the official donor sector, which will likely be targeted towards longer-term large-scale infrastructure investments, as well as Nigeria's budget (Leigh, 2008).

According to Awolusi (2012b) and Olajide et al. (2012), despite the positive impact of MNCs on growth, FDI and trade, the reverse was the case for domestic investment. This general lack of inducement for domestic investment might be due to inconsistent government policies, poor infrastructural development, political instability and low human capital development; hence, Nigeria witnessed a deteriorating growth and life expectancy during the period under review (Akinlo, 2004; UNDP, 2007).

\section{Conclusion}

Multinational corporations have spurred up economic activities in Nigeria. Multinational firms transfer technology directly to their foreign-owned subsidiaries and indirectly to their domestic enterprises in host countries. They create employment opportunities and improve the standard of living in host countries. Most citizens of the host countries who were recruited and trained by foreign firms acquire the knowledge and skills used to work in these firms and to start their own business. Through the presence of foreign direct investment in host countries, the host countries have witnessed improved balance of payment and increased financial and capital resources. Also, the Nigerian government have been able to expand their tax base through the generated income of multinational firms. Tax paid by foreign firms has been used to provide infrastructures and boost the economy of the nation. Nigeria as a major recipient of foreign direct investment has benefitted more than any country in West Africa from foreign direct investment in the region.

To reap the full benefits of Multinational corporations, nations should understand the magnitude of technology transfer, and its impact on economic development; hence, host governments should strategize their existing policies and institutions, rather than merely attracting FDI, and should focus additionally on effective transfer of technology, which includes the diffusion and generation of technology locally, (Lee and Tan, 2006). Policymakers need to know that, contrary to expectations, FDI may not lead to growth, rather, may increase both markets and economic risks; however, adequate provision should be made for all risks associated with FDI from MNCs, since increases risk premium, discourages investment, as well as the lower capacity of domestic firms, as a result of enhanced and unbalanced competition in the new 'globalised world' (Awolusi, 2012; Awolusi, 2012b). 


\section{References}

Abdul-Gafaru, A. (2006). Are multinational corporations compatible with sustainable development? The experience of developing countries. Georgia Tech Center for International Business Education and Research, Working Paper

Akanegbu, N.B. (2014). The impact of multinational oil corporation on the Nigerian economy: An empirical analysis. European Journal of Social Sciences, Arts, and Humanities, Vol. 2(2): pages 22-31.

Akinlo, A. E. (2004). "Foreign direct investment and growth in Nigeria An empirical Investigation", J. Policy Model., Vol. 26, pp. 627-639

Aitken, B. J, Hanson GH, Harrison AE (1997). Spillovers, foreign investment, and export behaviour. J. Int. Econ., 43,103-132.

Awolusi, O.D. (2012), "Foreign Direct Investment and Economic Growth in Nigeria: A Vector Error Correction Modeling”, Journal of Research in Economics and International Finance, Vol. 1(3) pp. 58-69.

Awolusi, O.D. (2012b), "Forecasting International Technology Transfer and International Trade in Nigeria: A Time Series Analysis", International Journal of Management and Networks Economics, Vol. 2, No.3, pp.282-297

Ayanwale, A.B. (2007). Foreign direct investment and economic growth: Evidence from Nigeria. African Economic Research Consortium, 165.

Bakare, A.S. (2010). Multinational direct investment and economic growth in Nigeria: An empirical study. International Business Management, 4 (3): 171-176.

Buckley, J. P.; Clegg, J. and Wang, C. (2002).“The impact of inward FDI on the performance of China's manufacturing firms", Journal of International Business Studies, Vol. 33(4), pp. 637-655.

Buckley, P. J.; Clegg, J.; Wang, C. and Cross, A. R. (2002b). "FDI, regional differences and economic growth: Panel data evidence from China". Transnational Corporation, Vol. 11, pp. $1-23$

Buckley, P.J.; Clegg, J. and Wang, C. (2006) "Inward FDI and host country productivity: evidence from China's electronics industry”. Transnational Corporations, Vol. 15(1), pp.14-36.

Buckley, J. P.; Wang, C. and Clegg, J. (2007). "The impact of foreign ownership, local Ownership and industry characteristics on spillover benefits from Foreign Direct Investment in China". International Business Review, Vol. 16(1), pp.142-158

Carkovic M, R Levine (2002). "Does Foreign Direct Investment Accelerate Economic Growth?" The University of Minnesota. May 2002, pp. 124-156 
Chukwuemeka, E., Anazodo, R., and Nzewi, H.N. (2011). African underdevelopment and the multinationals: A political commentary. Journal of Sustainable Development, 4 (4):101109.

Cundiff, K. (2000). International Business. Singapore: Indian Pearson Education Pte Ltd.

Diamant, R., Davison, H., and Pugatch, M.P. (2007)."Promoting technology transfer in developing countries: Lessons from public-private partnerships in the field of pharmaceuticals". Stockholm Network, 1 - 31 .

Dike, V.E. (2012). "Human capital development, technological capabilities, economic transformation: A critical review of the issues facing Nigeria in her quest for national development". Online Journal of Social Sciences Research, 1: 1-16.

Equity Research Report (2009) on Nestle Nigeria Plc. Retrieved from www.leadcapitalng.com/resources/nestle.pdf

Grossman, G.M, and Helpman, E. (1995). "Technology and Trade," in Gene Grossman and Kenneth Rogoff, eds. Handbook of International Economics, vol. 3, NA: Elsevier Science.

Hashimu, B. and Ango, N.A. (2012). Multinational companies' corporate social responsibility performance in Lagos State, Nigeria. A quantitative analysis. European Journal of Globalization and Development Research, 5(1): 247-266.

Hill, C.W.L. (2005). International business: Competing in the global marketplace. 5th Edition. New York: McGraw-Hill Companies Inc.

Hoekman, B. M.; Maskus, K. E. and Saggi, K. (2004). "Transfer of technology to developing countries: unilateral and multilateral policy options", World Bank Policy Research Working Paper 3332.

Ibidunni, O.S. (2009). Impact of competitive marketing on performance of multinational and indigenous food and beverage manufacturing companies in Nigeria. A Ph.D thesis done and submitted at Covenant University, Ota, Ogun State.

Ikiara, M. M. (2003). "Foreign Direct Investment (FDI), Technology transfer, and Poverty Alleviation: Africa's Hope and Dilemma", ATPS Special Paper Series No. 16, Nairobi: African Technology Policy Studies Network, pp. 1-38

Ilemona, A. (2010). Accelerating economic growth in Nigeria: The role of foreign direct investment. Current Research Journal of Economic Theory, 2(1): 11-15.

Javorcik, B. S. and Spatareanu, M. (2008). "To share or not to share: Does local Participation matter for spillovers from foreign direct investment?". Journal of Development Economics, Vol. 85, pp. 194-217

Kim, W. C. (2000). The changing nature of multinational business. Strategic Management Journal, 18(3): 145-152. 
Kumar N (1996). "Foreign Direct Investments and Technology Transfers in Development: A Perspective on Recent Literature". Institute for New Technologies (INTECH) Discussion Paper No. 9606, The United Nations University, Maastricht, The Netherlands.

Lee, H. H. and Tan, H. B. (2006). "Technology Transfer, FDI and Economic Growth in the ASEAN Region”. Journal of the Asia Pacific Economy, Vol. 11(4), pp. 394-410

Leigh, K. (2008). “The Nigerian FDI challenge”, Business Day, July 1st Edition

Lucas R (1988). "On the mechanics of economic development". Journal of Monetary Econ., Vol. 22(3), pp. 3-42.

Mahe, S. A., (2005). "Is Globalisation capable of raising living standard, through international trade in Nigeria?", Holler Africa Magazine (daily online): Adonis \& Abbey Publishers Ltd

Markusen, J.R, Venables, A.J. (2005). “A Multi-Country Approach to Factor- Proportions Trade and Trade Costs", NBER Working Paper No. 11051, January

Olajide, O.T., Akinlabi, B.H., and Tijani, A.A. (2012). Agriculture resource and economic growth in Nigeria. European Scientific Journal, 8 (26): 103-115.

Onodugo, V.A. (2012). Multinational corporations and employment and labour conditions of developing countries: The Nigerian experience. European Journal of Business and Social Sciences, 1(6): 67-76.

Otokiti, B.O. (2012). Mode of entry of multinational corporations and their performance in the Nigerian market. An M.Sc Research Project Done and Submitted at Covenant University, Ota, Ogun State.

Otusanya, O.J., Lauwo, S., and Adeyeye, G.B. (2012). A critical examination of the multinational companies' anti-corruption policy in Nigeria. Accountancy Business and the Public Interest. Department of Accounting Faculty of Business Administration University of Lagos.

Olise, M.C., Anigbogu, T.U., Okoli, M.I., and Anyanwu, K.N. (2013). Domestic investment and foreign direct investment flows in Nigeria. Journal of Humanities and Social Science, Vol. 13(6): pages 1-12.

Osuagwu, G.O. and Ezie, O. (2013). Multinational corporations and the Nigerian economy. International Journal of Academic Research in Business and Social Sciences, Vol. 3(4): pages $359-368$.

Ozoigbo, B.I. and Chukuezi, C.O. (2011). The impact of multinational corporations on the Nigerian economy. European Journal of Social Sciences, Vol. 19 (3), pages $34-46$

Quinlivan, G. (2005). Sustainable development: The role of multinational corporations. Retrieved from www.andrew.cmu.edu/course/73-371/UN_article.doc American Journal of Environmental Policy and Management 2015; 1(2): 16-24 24 
Rotimi, E.M., Obasaju, B., Lawal, A., and Ise Olorunkanmi, J. (2013). Analysis of corruption and economic growth in Nigeria. Afro Asian Journal of Social Sciences, Vol. 4 (4): pages $1-18$.

Romer, P. (1986). "Increasing Returns and Long-run Growth," Journal of Political Economy, Vol. 94, pages 1002-1037.

Subair, K. and Salihu, O. (2011). Foreign direct investment and development of small and medium scale enterprises in Nigeria. African Journal of Accounting, Economics, Finance, and Banking Research, Vol7(7): pages 64-77.

Tatum, M. (2010). The activities of multinational. Retrievedfromwww.wisegeek.com/what-isa-multinationalcorporation.htm

Tirimba, O.I. and Macharia, G.M. (2014). Economic impact of multinational corporations on development of developing nations. International Journal of Scientific and Research Publications, Vol. 4(9): pages 1-6.

Thompson, E.R. (2002). "Clustering of Foreign direct investment and Enhanced Technology Transfer: Evidence from Hong Kong Garment firms in China". World Development, Vol. 30 (5), pages .873-889

UNCTAD (2009). Capital flows and growth in Africa. New York: United Nations.

UNCTAD, (2002). Trade and development report 2002., United Nations, New York and Geneva 